\title{
New U-Pb ages for mafic dykes in the Northwestern region of the Ukrainian shield: coeval tholeiitic and jotunitic magmatism
}

\section{Leonid Shumlyanskyy, Richard E. Ernst, Ulf Söderlund, Kjell Billström, Oleksandr Mitrokhin \& Stepan Tsymbal}

To cite this article: Leonid Shumlyanskyy, Richard E. Ernst, Ulf Söderlund, Kjell Billström, Oleksandr Mitrokhin \& Stepan Tsymbal (2016) New U-Pb ages for mafic dykes in the Northwestern region of the Ukrainian shield: coeval tholeiitic and jotunitic magmatism, GFF, 138:1, 79-85, DOI: 10.1080/11035897.2015.1116602

To link to this article: http://dx.doi.org/10.1080/11035897.2015.1116602

曲 Published online: 10 Feb 2016.

Submit your article to this journal $₫$

山 Article views: 9

Q View related articles $₫$

View Crossmark data ¿ 


\title{
New $\mathrm{U}-\mathrm{Pb}$ ages for mafic dykes in the Northwestern region of the Ukrainian shield: coeval tholeiitic and jotunitic magmatism
}

\author{
LEONID SHUMLYANSKYY ${ }^{1}$, RICHARD E. ERNST ${ }^{2}$, ULF SÖDERLUND ${ }^{3,4}$, KJELL BILLSTRÖM ${ }^{4}$, \\ OLEKSANDR MITROKHIN ${ }^{5}$ and STEPAN TSYMBAL ${ }^{1}$
}

Shumlyanskyy, L., Ernst, R. E., Söderlund, U., Billström, K., Mitrokhin, O. \& Tsymbal, S., 2016: New $\mathrm{U}-\mathrm{Pb}$ ages for mafic dykes in the Northwestern region of the Ukrainian shield: coeval tholeiitic and jotunitic magmatism.GFF,Vol.138,No.1,pp.79-85.@ GeologiskaFöreningen.doi:http://dx.doi.org/10.1080/11035897. 2015.1116602 .

\begin{abstract}
The palaeoproterozoic Northwestern region of the Ukrainian shield hosts two compositional types of mafic dykes and associated magmatism that intruded at c. 1800-1760 Ma: (1) high-Ni dolerite dykes and layered intrusions of tholeiitic affinity and (2) high-Ti dolerite dykes of jotunitic affinity associated with anorthosite-mangerite-charnockite-granite (AMCG) suites. The jotunitic dykes represent initial melts for basic rocks of the Korosten AMCG plutonic complex, whereas tholeiitic dykes may reflect emplacement of a mantle plume and formation of a large igneous province (LIP). New U-Pb baddeleyite ages indicate that both compositional types can be coeval: the jotunitic Rudnya Bazarska dyke was emplaced at $1793 \pm 3 \mathrm{Ma}$, and the Zamyslovychi tholeiitic dolerite dyke at $1789 \pm 9 \mathrm{Ma}$. In our model, the mantle plume-derived tholeiitic melts (underplate) supplied heat required for melting of the mafic lower crust and the production of jotunitic melts. As formation of the jotunite melts requires pressures in the range 10-13 kbar, either a thickened crust is needed or the lower crust must be subducted, or downthrusted, into the mantle. Alternatively, emplacement and ponding of large volume of tholeiitic melts might cause delamination of the lower crust, its sinking into the mantle, and further fusion to produce jotunitic melts.
\end{abstract}

Keywords: palaeoproterozoic; Ukrainian shield; U-Pb dating; zircon; baddeleyite; mafic dykes

${ }^{I}$ Department of Geochronology, M.P. Semenenko Institute of Geochemistry, Mineralogy and Ore Formation, Palladina ave., 34, 03142 Kyiv, Ukraine; lshumlyanskyy@yahoo.com, tsymbal@igmof.gov.ua

${ }^{2}$ Department of Earth Sciences, Carleton University, Ottawa, Ontario, Canada; Richard.Ernst@ErnstGeosciences.com

${ }^{3}$ Department of Geology, Lund University, Sölvegatan 12, SE 22362 Lund, Sweden; Ulf.Soderlund@ geol.lu.se

${ }^{4}$ Department of Geological Sciences, Swedish Museum of Natural History, Box 50007, SE-10405 Stockholm,

Sweden; kjell.billstrom@nrm.se

${ }^{5}$ Geological department, Kyiv Taras Shevchenko National University, Vasylkivska st., 90, Kyiv, Ukraine;

Mitrokhin.A.V@yandex.ua

Manuscript received 17 April 2015. Revised manuscript accepted 02 November 2015.

\section{Introduction}

The Northwestern domain of the Ukrainian shield is composed of two palaeoproterozoic orogenic belts that were formed at c. 2.15-2.05 Ga (Teteriv-Zhytomyr orogenic belt) and at c. 2.0-1.95 Ga (Osnitsk-Mikashevychi igneous belt, OMIB). The Teteriv-Zhytomyr orogenic belt occurs as an accretionary prism composed of metapelitic sedimentary rocks, carbonate rocks and various metavolcanic rocks metamorphosed at amphibolite facies and intruded by numerous granitic intrusions. In contrast, the OMIB developed as an active continental margin and is composed of a bimodal volcano-plutonic association (Shumlyanskyy 2014). Both belts were intruded at 1800-1740 Ma by the anorogenic Korosten anorthosite-mangerite-charnockite-granite (AMCG) complex (Fig. 1). The causes of this last phase of magmatism (c. 1800-1740 Ma) are debated. An origin related to zones of extension produced during tectonic plate reorganization (collision of Fennoscandia and Volgo-Sarmatia) has been proposed (Bogdanova et al. 2013; Cawood and Buchan 2007; Cawood et al. 2009). However, the dolerite dykes associated with this magmatism have similarities to other major swarms associated with large igneous provinces (LIPs) for which a plume origin is typically preferred (Ernst 2014 and references therein). Here, we use the dyke record of c. 1800-1740 Ma magmatism 
to provide constraints on the origin of this NW Ukrainian shield magmatic province.

Three mafic dyke generations were recognized in this area (Shumlyanskyy et al. 2012). The oldest generation (c. $2.0 \mathrm{Ga}$ ) represented by epidote facies metamorphosed dolerite is related to the OMIB and it was briefly described by Elming et al. (2010) and Shumlyanskyy (2014). Dykes of high-Ti dolerites (jotunites) that belong to the second generation are distributed in the vicinity of the Korosten AMCG complex and represent the initial lower crustal melts of this complex. The third generation embraces a group of Ni-enriched dykes and layered intrusions of tholeiitic composition that were previously regarded either as feeders for a now completely eroded continental flood basalt sequence (Shumlyanskyy et al. 2002) or as products of crystallization of a mantle-derived tholeiite melt developed in response to collision of two large crustal segments that comprise the East-European platform, i.e. Fennoscandian and Volgo-Sarmatian segments (Shumlyanskyy et al. 2012; Bogdanova et al. 2013). These dykes of tholeiite affinity of c. $1.8 \mathrm{Ga}$ age occur throughout the whole of Sarmatia, including the Ukrainian shield (Bogdanova et al. 2013; Shumlyanskyy et al. 2015) and the Voronezh crystalline massif. In the Ukrainian shield, in addition to typical tholeiites, there are also subalkaline mafic and ultramafic rocks, and kimberlites of the same age (Shumlyanskyy et al. 2015).

In this paper, we present geochronology for the second (jotunitic) and third (tholeiitic) generations of dykes of the Northwestern region of the Ukrainian shield and discuss their possible relationships, based on the new ages.

\section{Geological setting}

Dykes of jotunitic (high-Ti monzogabbroic) affinity cut rapakivi-like granites and anorthosites of the northern and western parts of the Korosten AMCG plutonic complex (KPC), as well as country rocks. These dykes were never found in the south-eastern part of the KPC, or in the areas to the east or south of it (Fig. 1). The jotunitic dykes are abundant both within and outside the complex and occur up to several tens of kilometres away from its western border. The youngest country rocks known to be cut by jotunitic dykes belong to the Topilnya Series that fills the Bilokorovychi basin (Shumlyanskyy et al. in press). Within the KPC, jotunitic dykes cut both felsic and basic rocks, but dominate within granites. Dykes are usually less than 10-m thick and up to few hundred metres long. There are two exceptions: the Zvizdal-Zalissya and the Rudnya Bazarska dykes (Fig. 1) occur as wide (up to $1500 \mathrm{~m}$ ) and long (up to $18 \mathrm{~km}$ ), weakly differentiated, high-Ti monzonitic dolerite bodies. The latter is a focus of $\mathrm{U}-\mathrm{Pb}$ baddeleyite dating in this paper. In the Bondary quarry jotunites occur as a series of subhorizontal (sill-like) bodies up to 3-4-m thick that intrude rapakivi-like granites of the Korosten complex, and have clear glassy contacts against the host granites. Geochronological data for the jotunitic dykes are still scarce. Amelin et al. (1994) and Verkhogliad (1995) have obtained a concordant age of $1760.7 \pm 1.7 \mathrm{Ma}$ for a plagioclase-porphyritic dolerite dyke that crops out nearby the Pugachivka village. A zircon age of $1799 \pm 10 \mathrm{Ma}$ was obtained for jotunitic dolerite of the Bilokorovychi dyke swarm (Shumlyanskyy and Mazur 2010). Finally, Lubnina et al. (2009) reported a U-Pb zircon age of $1751 \pm 12 \mathrm{Ma}$ for the Bondary jotunite sill.
Tholeiitic dolerites of the Northwestern region of the Ukrainian shield were summarized by Shumlyanskyy et al. (2012) and Bogdanova et al. (2013). These rocks occur as numerous dykes and several layered intrusions confined to the major regional fault zones. Dykes are variable in size, their width varies from metres up to $500 \mathrm{~m}$, lengths reach $12 \mathrm{~km}$, and groups of dykes can be traced for $50 \mathrm{~km}$ and more (e.g. Tomashgorod dyke; Shumlyanskyy 2008). All dykes of this group, except one, are located outside of the KPC where they cut various country rocks, the youngest of which belongs to the OMIB. However, one tholeiitic dyke belonging to this group was recently discovered in the Malyn quarry where it cuts granite of the KPC. This dyke shows that tholeiitic magmatism accompanied formation of the KPC or is later. Most of the tholeiitic dykes are Ni-enriched ( $>100 \mathrm{ppm} \mathrm{Ni)}$ and comprise olivine-pigeonite and pigeoniteaugite dolerites and gabbro. A low-Ni variety of dolerite is also known although it is less common. In their central parts, thick dykes often contain pods of pegmatitic dolerite enriched with felsic interstitial material that contains baddeleyite and zircon suitable for $\mathrm{U}-\mathrm{Pb}$ dating.

The Prutivka intrusion is a typical representative of the Ni-enriched layered intrusions and occurs as an almost concordant sheet-like dolerite body with a thickness varying from 110 to $210 \mathrm{~m}$ and extending along strike for over $3 \mathrm{~km}$. It dips gently $\left(23-35^{\circ}\right)$ towards the south-east and was traced by drill holes to a depth of up to $800 \mathrm{~m}$. Syngenetic rock types of the Prutivka intrusion include plagioclase-bearing wehrlite, melatroctolite, troctolite, olivine gabbro, gabbro, quartz-bearing gabbro and gabbro-pegmatite. Three zones were recognized in a vertical section of the Prutivka intrusion: (1) contact zone; (2) a basal zone composed of melagabbro and ultramafic rocks and (3) a thick main zone composed of fine- to medium-grained dolerite that alternates rhythmically with coarse-grained (pegmatoid) dolerites (Shumlyanskyy et al. 2012). The Prutivka intrusion hosts the only known (subeconomic) Ni-Cu-PGE sulphide deposit within the Ukrainian shield (Skobelev et al. 1991).

The Kamyanka massif is a $>1000$-m-layered intrusion that served, probably, as a shallow-seated magma chamber. It is differentiated and composed of rocks varying in composition from peridotite in the bottom part to anorthosite in the upper portion of the intrusion. In the bottom part, it also contains low-grade disseminated Ni-Cu-PGE sulphide mineralization.

Ages of the Ni-bearing tholeiite rocks were reported by Shumlyanskyy et al. (2012) and Bogdanova et al. (2013) as follows: zircons from the Tomashgorod dyke pegmatite pod yielded a U-Pb age of $1787.4 \pm 6.4 \mathrm{Ma}$, whereas baddeleyite dating of dolerite from the same dyke gave an age of $1790.7 \pm 5.1 \mathrm{Ma}$. Pegmatitic dolerite of the Prutivka intrusion yielded a zircon age of $1777.0 \pm 4.7 \mathrm{Ma}$, recently confirmed by U-Pb baddeleyite age of $1779.2 \pm 6.9 \mathrm{Ma}$. Finally, the Kamyanka massif was dated by two zircon grains at c. $1.79 \mathrm{Ga}$.

In addition to tholeiite dykes variably enriched in $\mathrm{Ni}$, the Northwestern region of the Ukrainian shield hosts several dykes of subalkaline olivine gabbro (Shumlyanskyy 1999), and a series of dykes and small intrusions of mafic and ultramafic alkaline rocks that belong to the Horodnytsya Complex (Tsymbal et al. 1997, 2008; Kryvdik et al. 2003). The geological relationships of these dykes with host rocks constrain their age as younger than $2100 \mathrm{Ma}$. Ages of scarce zircons separated from these rocks were summarized by Tsymbal et al. (2014). Ages of individual grains vary from $2014 \pm 15$ to $2094 \pm 8 \mathrm{Ma}$, both 


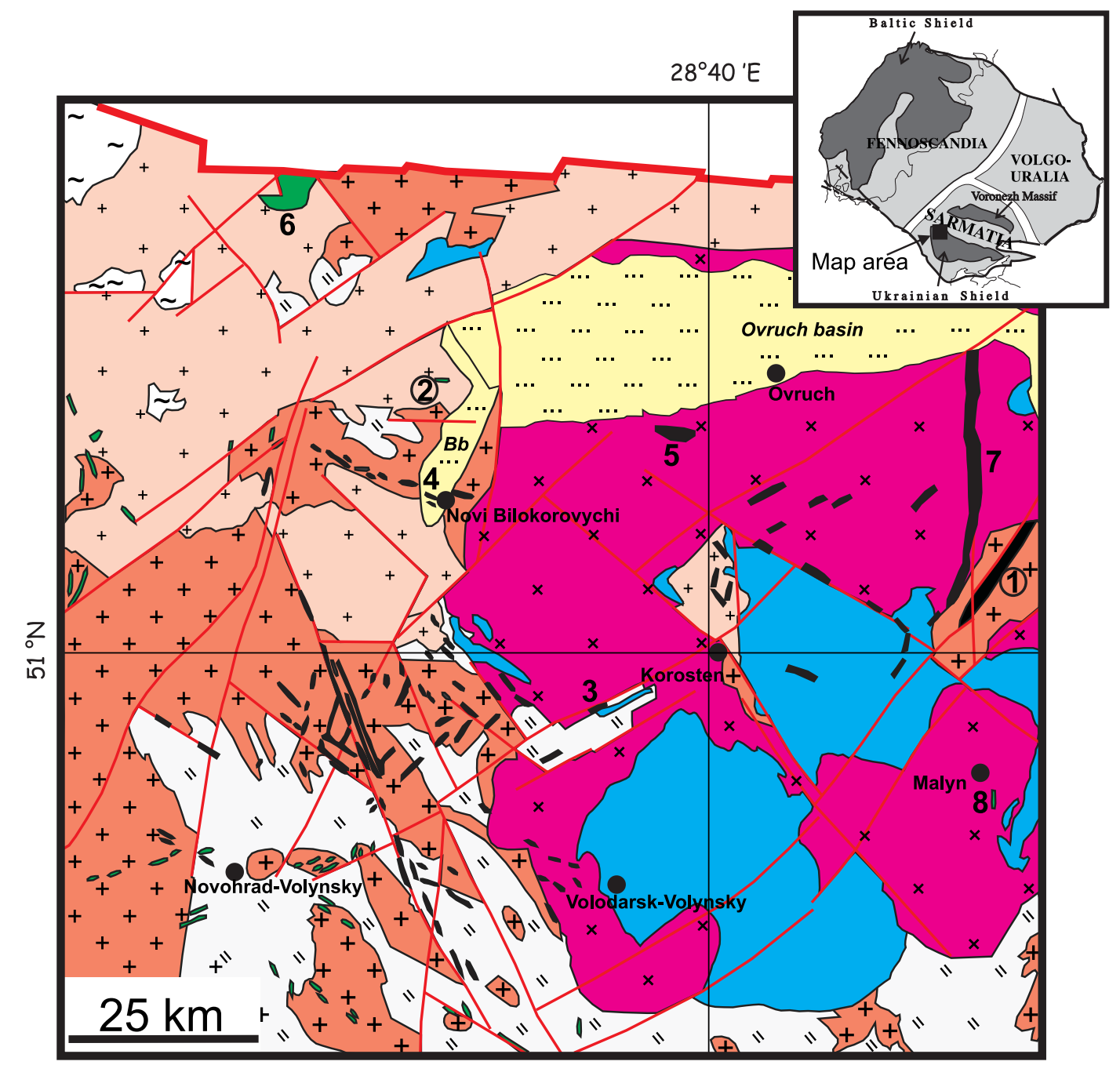

dykes of tholeiitic (c. 1790-1780 Ma) and unknown affinity

\section{Korosten AMCG plutonic complex}

basic rocks (anorthosite, leucogabbro, gabbro), 1800-1760 Ma granites, 1815-1740 Ma

dykes of jotunitic affinity, c. 1760-1800 Ma

effusive and clastic sediments of the Ovruch and Bilokorovychi $(\mathrm{Bb})$ basins, c. 1900-1700 Ma (oldest, weakly metamorphosed platformal sediments)

\section{Osnitsk-Mikashevychi igneous belt}

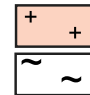
rocks of the Osnitsk Complex, c. 1980-2000 Ma metavolcanites of the Klesiv Series, c. 1980-2000 Ma

\section{Teteriv-Zhytomyr orogenic belt}

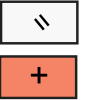
metamorphic rocks of the Teteriv Series, c. $2100-2150 \mathrm{Ma}$
granites and migmatites of the Zhytomyr Complex, c. 2040-2080 Ma

Fig. 1. Schematic geological map of the Korosten plutonic complex showing location of the studied dykes. Dated intrusive bodies are indicated by numbers ( 1 and 2 were dated in this study): 1 - Rudnya Bazarska dyke (1793 Ma); 2 - Zamyslovychi dyke (1789 Ma); 3 - Pugachivka dyke (1761 Ma, Amelin et al. 1994; Verkhogliad 1995); 4 - Bilokorovychi dyke (1799 Ma, Shumlyanskyy and Mazur 2010); 5 - Bondary sill (1751 Ma, Lubnina et al. 2009); 6 - Kamyanka massif (c. 1790 Ma, Shumlyanskyy et al. 2012). The Prutivka-layered dolerite body (1777 Ma, Shumlyanskyy et al. 2012) and the Tomashgorod dyke (1790 Ma, Shumlyanskyy et al. 2012; Bogdanova et al. 2013), discussed in the text, are located outside of the map. In addition, undated Zvizdal-Zalissya (7) and Malin (8) dykes are also shown. 
within each intrusion and between different intrusions. These ages are close to the ages of granitic rocks throughout the area and the dates may reflect analyses of zircon xenocrysts from the country rocks. Hence, the youngest age, $2014 \pm 15 \mathrm{Ma}$, is considered as the maximum age of the alkaline rocks of the Horodnytsya complex.

\section{Sample descriptions}

\section{Jotunitic dyke}

As discussed above, the Rudnya Bazarska dyke (sample U8227) is the second largest dyke associated with the KPC. It is 1000$1500-\mathrm{m}$ wide and up to $18-\mathrm{km}$ long, and trends at $\sim 040^{\circ}$. It is located in the north-eastern part of the KPC and cuts granites and migmatites of the Zhytomyr Complex (Fig. 1). The dyke does not crop out at surface. It is buried under Mesozoic and recent sediments in the south and the northernmost part of the dyke is covered by c. 1760 Ma old metavolcanics and metasediments of the Vilcha basin. Baddeleyite for $\mathrm{U}-\mathrm{Pb}$ dating was separated from a dolerite sample from drill hole \#1210 at a depth of $88 \mathrm{~m}$.

\section{Tholeiite dyke}

The Zamyslovychi dyke (sample 6440) is a 5-km long and 500-m thick intrusion that dips at $>80^{\circ}$ northwards (Fig. 1). Host rocks are granitoids of unknown affinity that were thermally affected at their contacts with the dyke. The predominant rock in the dyke is olivine dolerite. Geochemically, this dolerite is similar to numerous dykes and layered intrusions of tholeiitic affinity in the area, but differs from those due to low concentrations of $\mathrm{Ni}$ (20$30 \mathrm{ppm}$ ) in spite of high $\mathrm{MgO}$ (7.3-9.5 wt. \%). Both baddeleyite and zircon were found in most samples of the Zamyslovychi dyke taken from drill hole 6440 that reached about 300-m depth. Zircons observed in thin sections occur as inclusions in biotite as small $(<200 \mu \mathrm{m})$ short-prismatic light-brownish crystals that do not show any significant signs of zonation. A large amount of zircon was found in olivine dolerite at a depth of 64.0-65.0 m. In thin sections, baddeleyite grains are associated with interstitial orthoclase, biotite and calcite. Baddeleyite occurs as large $(0.05 \times 0.3-0.4 \mathrm{~mm})$ dark-brownish crystals.

\section{Methods}

The zircon-bearing sample was initially processed at the Institute of Geochemistry, Mineralogy, and Ore Formation, Kyiv, Ukraine, employing conventional separation methods (water shaking table, heavy liquids and a magnetic separator). Zircon grains were handpicked from the heavy mineral fraction under a binocular microscope.

Samples U8227 (Rudnya Bazarska dyke) and 6440 (Zamyslovychi dyke) were processed at Lund University, Sweden, and baddeleyite was extracted using the Söderlund and Johansson (2002) method. The baddeleyite grains from both samples are of optically good quality. Fractions of 2-6 grains in each were analysed on a TRITON thermal ionisation multicollector mass spectrometer at the Swedish Museum of Natural History in Stockholm. The filaments were heated in a high vacuum in the mass spectrometer, and $\mathrm{Pb}$ isotopes were measured after heating to a temperature range of approx- imately $1200-1250{ }^{\circ} \mathrm{C} .{ }^{204} \mathrm{~Pb},{ }^{205} \mathrm{~Pb},{ }^{206} \mathrm{~Pb},{ }^{207} \mathrm{~Pb}$ and ${ }^{208} \mathrm{~Pb}$ were measured in either static mode with Faraday Cups, or in peak-switching mode with a secondary electron multiplier amplifier. The temperature was then increased to approximately $1270-1320{ }^{\circ} \mathrm{C}$ to measure the intensities of ${ }^{235} \mathrm{U}$ and ${ }^{238} \mathrm{U}$ in peak-switching mode. An "inhouse" programme made by Per-Olof Persson (Swedish Museum of Natural History, Stockholm) with calculations following Ludwig (2012) was used for data handling. Details of sample preparation, mass spectrometry analysis and data reduction are given in Olsson et al. (this volume).

${ }^{207} \mathrm{~Pb} /{ }^{206} \mathrm{~Pb}$ dates of zircon from sample 6440 (Zamyslovychi dyke) were performed at Bristol University, UK. The data were acquired with a Thermo-Scientific Neptune multi-collector ICPMS coupled to a New Wave $193 \mathrm{~nm}$ ArF laser ablation sampling system operating at $4 \mathrm{~Hz}$ and using a $50-\mu \mathrm{m}$ spot size over a 60 $\mathrm{s}$ ablation period.

\section{Results}

\section{Jotunitic dyke}

Two of the three baddeleyite fractions analysed from the Rudnya Bazarska dyke (sample U8227) overlap and almost concordant within error (Table 1, Fig. 2). Free regression yields an upper intercept age of $1793 \pm 3 \mathrm{Ma}$ with a lower intercept of $52 \pm 720 \mathrm{Ma}$ (MSWD < 0.1). The upper intercept age is interpreted to date the emplacement of this dyke.

\section{Tholeiite dyke}

The four baddeleyite fractions from the Zamyslovychi dyke define linear array in the U-Pb concordia diagram (Fig. 2; Table 1). Regression yields an upper intercept of $1789 \pm 9 \mathrm{Ma}$ and a lower intercept of $926 \pm 460 \mathrm{Ma}(\mathrm{MSWD}<0.1)$. Fraction b plots concordant within error and its ${ }^{207} \mathrm{~Pb} /{ }^{206} \mathrm{~Pb}$ date is $1786 \pm 4 \mathrm{Ma}$. This date is considered as a minimum age of dyke emplacement. The meaning of the lower intercept is not easy to explain, since no metamorphic event of this age has been reported from the Northwestern region of the Ukrainian shield. Nevertheless, we interpret the upper intercept age of $1789 \pm 9 \mathrm{Ma}$ as the best estimate for crystallization of this dyke.

The weighted average ${ }^{207} \mathrm{~Pb} /{ }^{206} \mathrm{~Pb}$ age for zircon from the Zamyslovychi dyke calculated for all five measurements is $2148 \pm 27 \mathrm{Ma}$ (Table 2 ). This age corresponds to the age of metamorphism of rocks of the Teteriv Series and migmatites of the Sheremetiv Complex (Tsymbal et al. 2014) that are abundant in the area, whereas the weighted average of $\varepsilon \mathrm{Hf}$ values at $2148 \mathrm{Ma}$ calculated for the same spots is $1.4 \pm 0.9$ and also corresponds to the Hf isotope composition in the host granitoids (Shumlyanskyy, unpubl. data). These results suggest that the zircon grains are inherited from the host rocks.

\section{Discussion}

Recent studies (Shumlyanskyy et al. 2012; 2015; Bogdanova et al. 2013) have revealed a wide distribution of c. 1800-1750 Ma mantle-derived mafic and ultramafic magmatism within the whole Sarmatia crustal block. This magmatism resulted in formation of tholeiitic dolerite dykes (both high-Ni and low-Ni varieties) and 
Table 1. Results of U-Pb TIMS baddeleyite dating of rocks of the Rudnya Bazarska and Zamyslovychi dykes.

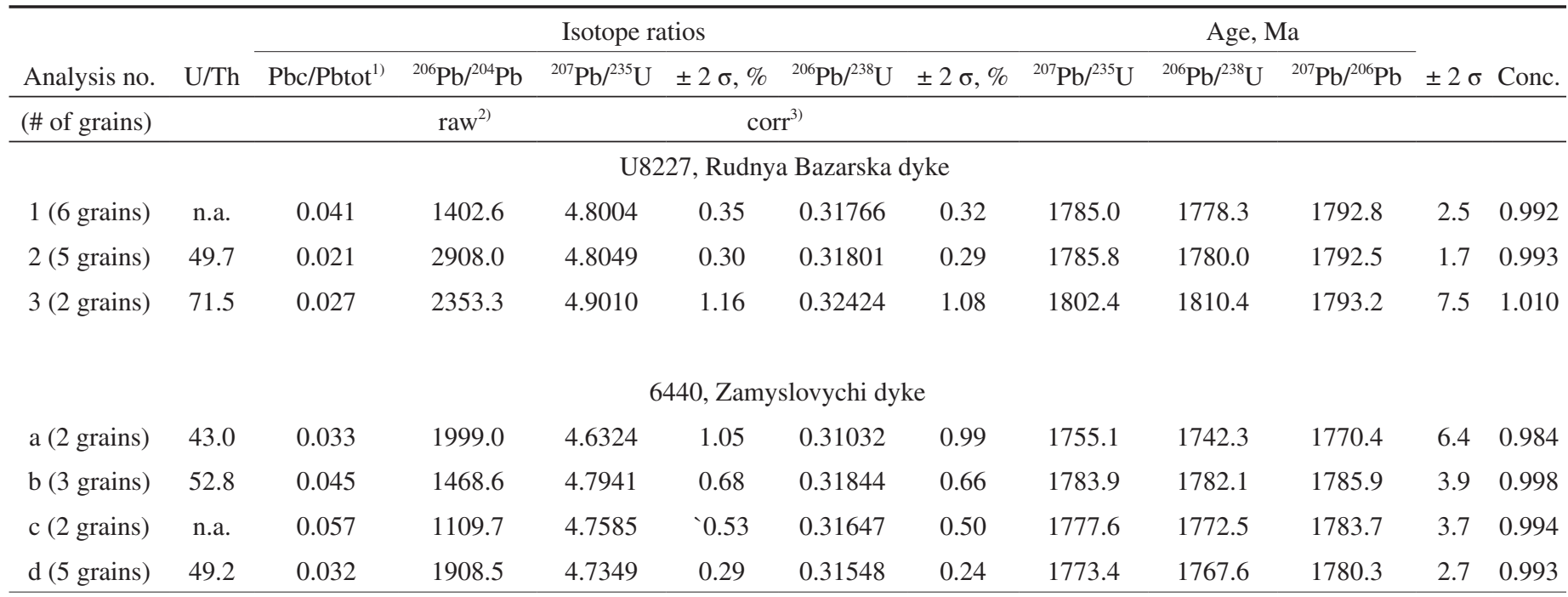

(1) $\mathrm{Pbc}=$ common $\mathrm{Pb} ; \mathrm{Pbtot}=$ total $\mathrm{Pb}($ radiogenic + blank + initial $)$.

(2) measured ratio, corrected for fractionation and spike.

(3) isotopic ratios corrected for fractionation ( $0.1 \%$ per amu for $\mathrm{Pb})$, spike contribution, blank ( $0.5 \mathrm{pg} \mathrm{Pb}$ and $0.05 \mathrm{pg} \mathrm{U})$ and initial common $\mathrm{Pb}$. Initial common $\mathrm{Pb}$ corrected with isotopic compositions from the model of Stacey and Kramers (1975) at the age of the sample.
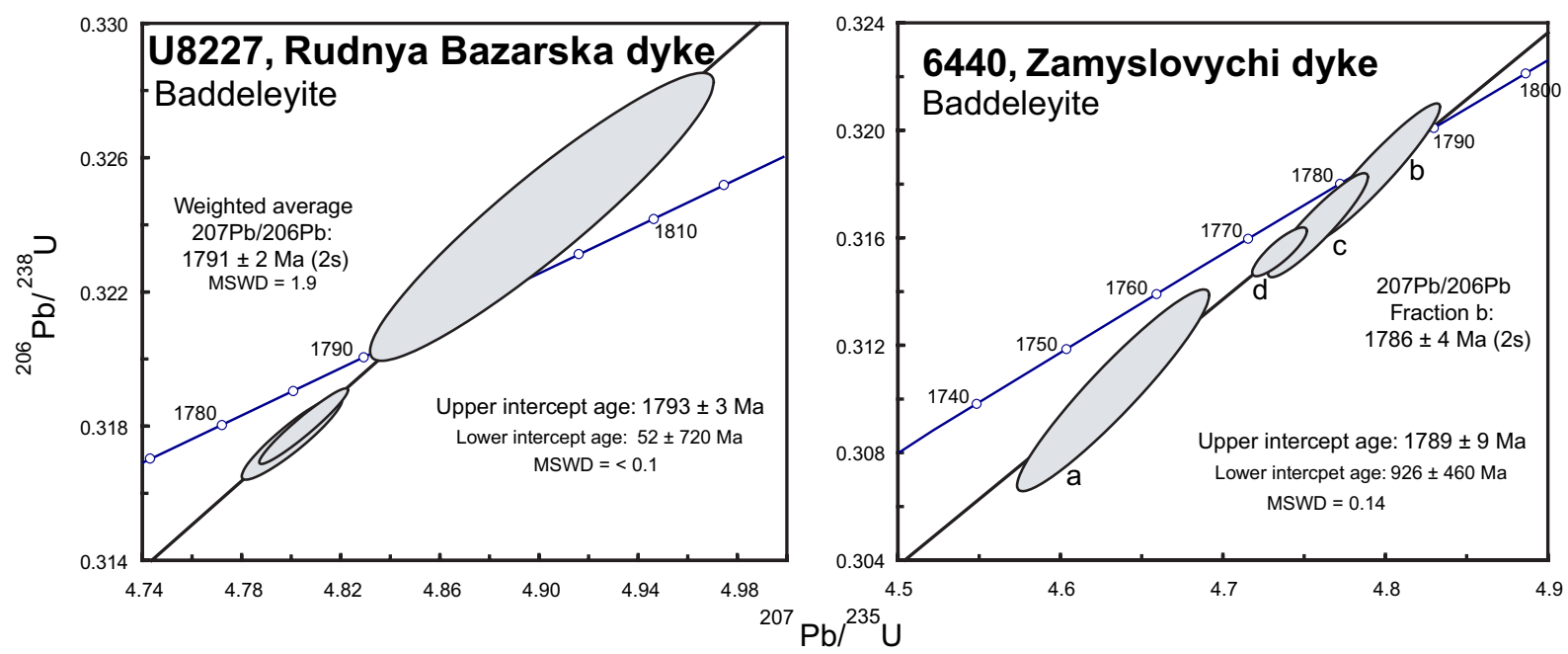

Fig. 2. U-Pb isotope diagrams for dykes of the Northwestern region of the Ukrainian shield.

Table 2. Pb and Hf isotope compositions in zircons from the Zamyslovychi dyke (sample 6440).

\begin{tabular}{|c|c|c|c|c|c|c|c|c|c|c|c|}
\hline Crystal & ${ }^{207} \mathrm{~Pb} /{ }^{206} \mathrm{~Pb}$ & $\sigma$ & Age, $\mathrm{Ma} \pm 1 \sigma$ & ${ }^{176} \mathrm{Lu} /{ }^{177} \mathrm{Hf}$ & ${ }^{176} \mathrm{Yb} /{ }^{177} \mathrm{Hf}$ & ${ }^{176} \mathrm{Hf} /{ }^{177} \mathrm{Hf}$ & $\sigma$ & ${ }^{176} \mathrm{Hf} /{ }^{177} \mathrm{Hf}$ & $\varepsilon \mathrm{Hf}$ & $\pm 2 \sigma$ & $\mathrm{T}_{(\mathrm{DM})} \mathrm{Ma}$ \\
\hline 1 & 0.12977 & 0.00056 & $2094.8 \pm 7.5$ & 0.000839 & 0.021232 & 0.281503 & 0.000029 & 0.281469 & 2.0 & 2.0 & 2435 \\
\hline 2 & 0.13033 & 0.00102 & $2102.4 \pm 13.8$ & 0.000842 & 0.021852 & 0.281493 & 0.000017 & 0.281458 & 1.6 & 1.2 & 2449 \\
\hline 3 & 0.14110 & 0.00403 & $2240.8 \pm 49.3$ & 0.000952 & 0.023100 & 0.281370 & 0.000063 & 0.281331 & -2.9 & 4.5 & 2624 \\
\hline 4 & 0.13534 & 0.00382 & $2168.5 \pm 49.2$ & 0.000862 & 0.021516 & 0.281482 & 0.000025 & 0.281446 & 1.2 & 1.8 & 2466 \\
\hline 5 & 0.13274 & 0.00121 & $2134.5 \pm 16.0$ & 0.000689 & 0.017662 & 0.281382 & 0.000126 & 0.281353 & -2.1 & 9.0 & 2590 \\
\hline
\end{tabular}

Note: Initial ${ }^{176} \mathrm{Hf} /{ }^{177} \mathrm{Hf}$ ratios and $\varepsilon \mathrm{Hf}$ values are calculated at $2148 \mathrm{Ma}$ for all crystals.

gabbroic-layered intrusions, dykes of subalkaline mafic rocks, alkaline and subalkaline ultramafic rocks and kimberlites, that taken together resemble an association typical of continental LIPs where the basaltic flows were completely eroded (Ernst 2014). 
Table 3. Summary of the U-Pb zircon and baddeleyite ages of jotunitic dolerites and tholeiites of the Northwestern region of the Ukrainian shield.

\begin{tabular}{cccll}
\hline$\#$ & Sample & Age, Ma & Location & Reference or method \\
\hline \multicolumn{1}{l}{ Jotunitic dolerites } & & & \\
1 & $23 / 90$ & $1760.7 \pm 1.7$ & village Pugachivka, dyke & Amelin et al. (1994); Verkhogliad (1995) \\
2 & 1025 & $1799 \pm 10$ & Bilokorovychi dyke & Shumlyanskyy and Mazur (2010) \\
3 & U8227 & $1793 \pm 3(\mathrm{bd})$ & Rudnya Bazarska dyke & this study, TIMS \\
4 & $06-$ BG47 & $1751 \pm 12$ & Bondary quarry, sill & Lubnina et al. (2009) \\
Tholeiites & & $1787.4 \pm 6.4$ & Tomashgorod dyke & \\
6 & & $1791 \pm 5(\mathrm{bd})$ & & Shumlyanskyy et al. (2012) \\
7 & 268 & $1777.0 \pm 4.7$ & Prutivka sill-like intrusion & Sogdanova et al. (2013) \\
8 & $3502 / 704$ & c. 1790 & Kamyanka-layered massif & Shumlyanskyy et al. (2012) \\
9 & 6440 & $1789 \pm 9(\mathrm{bd})$ & Zamyslovychi dyke & this study, TIMS \\
\hline
\end{tabular}

Note: All data are results of zircon dating, unless stated otherwise; bd - baddeleyite.

In the Ukrainian shield rocks of this LIP affinity are very abundant in the Northwestern and central (Ingul terrain) parts of the shield, where they are closely associated in time and space with the palaeoproterozoic Korosten and Korsun-Novomyrgorod AMCG plutonic complexes, respectively (Bogdanova et al. 2013; Shumlyanskyy et al. 2015). Initial melts for basic rocks of these AMCG complexes were probably of high-Ti subalkaline (jotunitic) composition as can be concluded from their occurrence as chilled margins of gabbroic massifs in these complexes. Further evidence of the jotunitic nature of the initial melts includes identity of the isotope composition of jotunitic-chilled margins and of basic rocks of these AMCG complexes. A detailed discussion of these relationships is beyond the scope of this short communication.

Both types of dykes (tholeiitic and jotunitic) occur along the same major trans-crustal shear zones and their accompanying faults. In the Northwestern region of the Ukrainian shield the tholeiite dykes are very abundant outside of the Korosten plutonic complex, whereas a single dyke (Malyn dyke) of tholeiitic affinity was revealed recently within the complex where it cuts the c. 1765 Ma granite. This indicates that tholeiite magmatism accompanied the Korosten plutonic complex during its formation. At the same time, jotunite dykes are common both outside and inside of the Korosten complex.

Geochemical and isotopic data indicate a moderately depleted mantle source for tholeiite magmatism of the Northwestern region of the Ukrainian shield (Shumlyanskyy et al. 2012; Bogdanova et al. 2013). The melting most probably occurred at a relatively shallow depth in the spinel peridotite stability field. Tholeiite melts intruded into the crust and ponded at the mantle-crust boundary.

It has been demonstrated that the isotope composition of the Korosten AMCG complex basic rocks (Shumlyanskyy et al. 2006), including jotunites, closely corresponds to the isotope composition of the Osnitsk-Mikashevychi rocks at the time of formation of the Korosten complex. In other words, the jotunitic melts, initial melts for the Korosten AMCG complex, could have been formed due to partial melting of the mafic lower crustal material formed during the Osnitsk orogeny.

Simultaneous formation of the tholeiite (mantle-derived) and jotunite (lower crustal-derived) melt was not accidental. As has been experimentally demonstrated (Vander Auwera et al. 1998,
2011; Longhi et al. 1999; Longhi 2005), jotunite melts cannot be derived from more mafic melts by fractional crystallization even with possible involvement of crustal contamination, whereas partial melting of lower crustal mafic (gabbronoritic) rocks was suggested as a possible source for jotunitic melts. In our model, emplacement and ponding of the mantle-derived tholeiitic melts at a lower crustal level supplied heat required for melting of the mafic lower crust and production of the jotunitic melts. However, formation of jotunite melts requires pressures in the range 10-13 kbar (40-50 km) (Longhi et al. 1999), i.e. either a thickened crust is required or the lower crust must be subducted or downthrusted into the mantle (Duchesne et al. 1999). Locally thickened crust might be a result of the previous orogenic event that took place 200 Myr prior to the formation of the KPC. Relicts of the subducted crust may also be present in the upper mantle.

Formation of the tholeiitic mantle-derived dykes and layered intrusions throughout Sarmatia and jotunitic dykes and related AMCG complexes coincides in time with oblique collision of Sarmatia and Fennoscandia. The collision has started at c. 1.83$1.81 \mathrm{Ga}$ and continued for the next $100 \mathrm{Myr}$, causing rotation of Sarmatia, crustal extension and mantle disturbance (Bogdanova et al. 2006). These processes may have led to the abundant mantle melting and formation of the dykes and layered intrusions of tholeiitic affinity (Shumlyanskyy et al. 2012; Bogdanova et al. 2013). However, the association of the mantle-derived rocks throughout the Ukrainian shield (Shumlyanskyy et al. 2015) and the whole of Sarmatia that includes tholeiites, sub-alkaline gabbro, alkaline mafic and ultramafic rocks and kimberlites would be typical for a mantle-plume induced LIP (Ernst 2014). Additional arguments in favour of a plume/LIP model are presented in the companion paper (Shumlyanskyy et al. 2015).

\section{Conclusions}

The Northwestern region of the Ukrainian shield hosts numerous dykes and small-layered intrusions that were emplaced during the late palaeoproterozoic, c. 1800-1760 Ma (Table 3). These belong to two distinct geochemical series, i.e. tholeiitic and jotunitic series. The new $\mathrm{U}-\mathrm{Pb}$ baddeleyite ages, obtained for two 
dykes in this area, confirm the contemporaneous emplacement of tholeiitic and jotunitic melts: the jotunitic Rudnya Bazarska dyke was emplaced at $1793 \pm 3 \mathrm{Ma}$, whereas the age of the Zamyslovychi dyke was defined as $1789 \pm 9 \mathrm{Ma}$.

Dykes of jotunitic affinity represent initial melts for basic rocks of the Korosten plutonic complex, whereas tholeiitic rocks, together with other mantle-derived rocks, can be interpreted in terms of emplacement of a mantle plume and formation of LIPs. Hence, our data allow suggestion of the existence of a direct link between the emplacement of the mantle plume and the formation of the AMCG complex. An alternative explanation is formation of the mantle- and lower crustal-derived melts due to lithospheric destabilization that was caused by oblique collision of Fennoscandia and Volgo-Sarmatia at 1.83-1.80 Ga.

In our model, the tholeiitic melts (generated by a mantle plume or due to lithospheric destabilization) emplaced at lower crustal level (magmatic underplate) supplied heat required for melting of the mafic lower crust and production of the jotunitic melts. As formation of the jotunite melts requires pressures in the range 10-13 kbar (40-50 km), either a thickened crust is needed or the lower crust must be subducted or downthrusted into the mantle. Alternatively, emplacement and ponding of large volumes of tholeiitic melts might cause delamination of the lower crust, its sinking into the mantle, and further fusion during sinking to produce jotunitic melts.

Acknowledgements-The guest editor Wouter Bleeker, and Fernando Corfu and an anonymous reviewer are thanked for their suggestions and comments which greatly helped improve the paper. This is publication number 52 of the 2010-2015 Large Igneous Provinces - Supercontinent Reconstruction - Resource Exploration Project (www.supercontinent.org; www.camiro.org/exploration/ongoing-projects).

\section{References}

Amelin, Y.V, Heaman, L.M., Verchogliad, V.M. \& Skobelev, V.M. 1994: Geochronological constraints on the emplacement history of an anorthosite-rapakivi granite suite: $\mathrm{U}-\mathrm{Pb}$ zircon and baddeleyite study of the korosten complex, Ukraine. Contributions to Mineralogy and Petrology 116, 411-419.

Bogdanova, S.V., Gintov, O.B., Kurlovich, D., Lubnina, N.V., Nilsson, M., Orlyuk, M.I., Pashkevich, I.K., Shumlyanskyy, L.V. \& Starostenko, V.I., 2013: Late palaeoproterozoic mafic dyking in the Ukrainian Shield (Volgo-Sarmatia) caused by rotations during the assembly of supercontinent Columbia. $\mathrm{Li}$ thos 174, 196-216.

Bogdanova, S., Gorbatschev, R., Grad, M., Janik, T., Guterch, A., Kozlovskaya, E., Motuza, G., Skridlaite, G., Starostenko, V., Taran, L., Eurobridge, Polonaise Working Groups, 2006: Eurobridge: new insight into the geodynamic evolution of the East European Craton. In D.G. Gee \& R.A. Stephensson (eds.): Geological Society, Memoirs, 599-625. European Lithosphere Dynamics, London. 32.

Cawood, P.A. \& Buchan, C., 2007: Linking accretionary orogenesis with supercontinent assembly. Earth-Science Reviews 82, 217-256.

Cawood, P.A., Kröner, A., Collins, W.J., Kusky, T.M., Mooney, W.D. \& Windley, B.F. 2009: Accretionary orogens through Earth history. Geological Society, London, Special Publications 318, 1-36.

Duchesne, J.C., Liégeois, J.P., Vander Auwera, J. \& Longhi, J. 1999: The crustal tongue melting model and the origin of massive anorthosites. Terra Nova 11, $100-105$.

Elming, S.-Å., Shumlyanskyy, L., Kravchenko, S., Layer, P. \& Söderlund, U. 2010: Proterozoic basic dykes in the Ukrainian shield: a palaeomagnetic, geochronologic and geochemical study - the accretion of the Ukrainian shield to Fennoscandia. Precambrian Research 178, 119-135.

Ernst, R.E., 2014: Large igneous provinces. Cambridge University Press, Cambridge. $653 \mathrm{pp}$.

Kryvdik, S.G., Tsymbal, S.N. \& Gejko, Y.V., 2003: Proterozojskij schelochno-ultraosnovnyj magmatizm severo-zapadnoj chasti Ukrainskogo schita kak indikator kimberlitoobrazovaniya [Proterozoic alkaline ultramafic magmatism of the North-Western region of the Ukrainian shield as an indicator of formation of kimberlites]. Mineralogichny zhurnal 25, 57-69. (In Russian).

Longhi, J., 2005: A mantle or mafic crustal source for Proterozoic anorthosites? Lithos 83, 183-198.

Longhi, J., Vander Auwera, J., Fram, M.F. \& Duchesne, J.C., 1999: Some phase equilibrium constraints of the origin of Proterozoic (massif) Anorthosites and related rocks. Journal of Petrology 40, 339-362.
Lubnina, N.V., Bogdanova, S.V. \& Shumlyanskyy, L.V., 2009: Vostochno-Evropejskij kraton $\mathrm{v}$ paleoproterozoe:novye paleomagnitnye opredeleniya po magmaticheskim kompleksam Ukrainskogo schita [East-European craton in Palaeoproterozoic: new palaeomagnetic determinations on igneous complexes of the Ukrainian shield]. Geofizika (Geophysics) 5, 56-64. (In Russian).

Ludwig, K.R., 2012. Isoplot 3.75. A geochronological toolkit for microsoft excel. Berkeley Geochronology Center Special Pubication 5. 75pp.

Shumlyanskyy, L.V., 1999: Formatsijna nalezhnist ta osoblyvosti rechovynnogo skladu dajok subluzhnogo olivinovogo gabro Volynskogo megabloka Ukrainskogo schita [Composition of dykes of subalkaline olivine gabbro, Volyn terrain of the Ukrainian shield]. Proceedings of the Kyiv University, Ser. Geology 15, 32-36 (In Ukrainian).

Shumlyanskyy, L.V. 2008: Petrologiya dolerytiv Tomashgorodskoj grupy dajok (Ukrainsky schyt) [Petrology of dolerites of the Tomashgorod group of dykes, Ukrainian shield]. Mineralogichny zhurnal 30, 17-35. (In Ukrainian).

Shumlyanskyy, L.V. 2014: Geochemistry of the Osnitsk-Mikashevichy volcanoplutonic complex of the Ukrainian shield. Geochemistry International 52(11), 912-924.

Shumlyanskyy, L., Billström, K., Hawkesworth, C. \& Elming, S.-Å. 2012: U-Pb age and $\mathrm{Hf}$ isotope compositions of zircons from the north-western region of the Ukrainian shield: mantle melting in response to post-collision extension. Terra Nova 24, 373-379.

Shumlyanskyy, L., Ellam, R.M. \& Mitrokhin, O. 2006: The origin of basic rocks of the Korosten AMCG complex, Ukrainian shield: implication of $\mathrm{Nd}$ and $\mathrm{Sr}$ isotope data. Lithos 90, 214-222.

Shumlyanskyy, L.V. \& Mazur, M.D. 2010: Age and composition of jotunites of the Bilokorovychi dyke swarm. Geologist of Ukraine 1-2, 70-78. (In Ukrainian).

Shumlyanskyy, L, Mitrokhin, O., Billström, K., Ernst, R., Vishnevska, E., Tsymbal, S., Cuney, M., \& Soesoo, A., 2015: The ca. 1.8 Ga mantle plume related magmatism of the central part of the Ukrainian shield. GFF. http://dx.doi.org/ 10.1080/11035897.2015.1067253

Shumlyanskyy, L., Petrenko, O. \& Omelchenko, A., in press: Bilokorovytska zapadyna na pivnichnomu zakhodi Ukrainskogo schita: geologichna pozytsiya, vik ta genezys [The Bilokorovychi depression at the Northwestern region of the Ukrainian shield: its geological setting, composition, age and origin]. Zapysky Ukrainskogo mineralogichnogo tovarystva, accepted. (In Ukrainian).

Shumlyanskyy, L.V., Zinchenko, O.V. \& Molyavko, O.V. 2002: Geologicheskoe polozhenie i osobennosti vschestvennogo sostava mezoproterozojskoj trappovoj assotsiatsii Severo-Zapadnogo bloka Ukrainskogo schita [Geological setting and composition of Palaeoproterozoic continental flood basalts of the North-Western region of the Ukrainian shield]. Mineralogichny zhurnal 24, 53-63. (In Russian).

Skobelev, V.M., Yakovlev, B.G., Galiy, S.A., Kogut, K.V., Chernyshov, N.M., Zajonts, I.O., Khomyak, T.P., Verkhogliad, V.M. \& Krochuk, V.M., 1991: Petrogenezis nikelenosnykh gabbroidnikh intruzivov Volynskogo megabloka Ukrainskogo schita [Petrogenesis of the Ni-bearing gabbroic intrusions of the Volyn terrain of the Ukrainian shield]. Naukova Dumka publisher, Kyiv, 140 pp. (In Russian).

Söderlund, U. \& Johansson, L. 2002: A simple way to extract baddeleyite $\left(\mathrm{ZrO}_{2}\right)$. Geochemistry, Geophysics, Geosystems 3 (2). doi: http://dx.doi.org/10.1029/2001GC000212.

Stacey, J.S. \& Kramers, J.D. 1975: Approximation of terrestrial lead isotope evolution by a two-stage model. Earth and Planetary Science Letters 26, 207-221.

Tsymbal, S.N., Gejko, Yu.V., Kryvdik, S.G., Baran, A.N. \& Tsymbal, Yu.S., 2008: Bolyarkovskaya intruziya schelochno-ultraosnovnykh porod (severo-zapad Ukrainskogo schita) [Bolyarkivska alkaline-ultramafic intrusion, North-Western region of the Ukrainian shield]. In: Actual problems of geology of Belarus and adjacent areas. Abstract volume of the International scientific conference (Minsk, 8-9 December 2008). - Minsk, p. 35-40. (In Russian).

Tsymbal, S.N., Scherbakov, I.B., Kryvdik, S.G. \& Labuzny, V.F. 1997: Schelochno-ultraosnovnye porody Gorodnitskoj intruzii (severo-zapad Ukrainskogo schita) [Alkaline-ultramafic rocks of the Horodnytsya intrusion, North-Western region of the Ukrainian shield]. Mineralogichny zhurnal 19, 61-80. (In Russian).

Tsymbal, S.N., Shumlyanskyy, L.V. \& Stepanyuk, L.M., 2014: Vozrast schelochno-ultraosnovnykh porod gorodnitskogo i granitoidov scheremetovskogo kompleksov severo-zapadnoj chasti Ukrainskogo schita [Age of the alkaline-ultramafic rocks of the Horodnytsya complex and of granitoids of the Sheremetiv complex of the North-Western region of the Ukrainian shield]. In: Geochronology and geodynamics of the Early Precambrian (3.6-1.6 Ga) of the Eurasian continent. Abstract volume of the International scientific conference dedicated to the 90-th anniversary of Academician of the NAS of Ukraine M.P. Sherbak, Kyiv, 16-17 September 2014, p. 121-122. (In Russian).

Vander Auwera, J., Bolle, O., Bingen, B., Liégeois, J.P., Bogaerts, M., Duchesne, J.C., De Waele, B. \& Longhi, J. 2011: Sveconorwegian massif-type anorthosites and related granitoids result from post-collisional melting of a continental arc root. Earth-Science Reviews 107, 375-397.

Vander Auwera, J., Longhi, J. \& Duchesne, J.C. 1998: A liquid line of descent of the jotunite (hypersthene monzodiorite) suite. Journal of Petrology 39, 439-468.

Verkhogliad, V.M. 1995: Vozrastnye etapy magmatizma Korostenskogo plutona [Age stages of magmatism of the Korosten pluton]. Geokhimiya ta rudoutvorennya $21,34-47$. (Russian). 